\title{
ON CRITIQUE, DISSENSUS AND HUMAN RIGHTS LITERACIES
}

\author{
C. Roux* \\ e-mail: cdr@sun.ac.za
}

\author{
A. Becker* \\ e-mail: annebecker@sun.ac.za \\ *Department of Curriculum Studies \\ Faculty of Education \\ Stellenbosch University \\ Stellenbosch, South Africa
}

\section{ABSTRACT}

Globally, issues such as xenophobia, rising nationalism and populism, linked to the international migrant crisis, are stretching the past influence and the present reinterpretation of the Universal Declaration of Human Rights (1948) to its limits. Locally, the \#MustFall ${ }^{1}$ protests at higher education institutions rightly question the existence and validity of human rights, especially as it pertains to the right to education, socio-economic rights and the moral responsibility of higher education institutions to its students within human rights policy frameworks. The growing critique of human rights is crucial not only to the understanding of the conceptual, legal, moral, historic and contextual complexities of human rights but also the rethinking of the anthropological, ethical, ontological and epistemological premise of human rights. Human rights literacies, we argue, while including knowledge about human rights, question the social and moral consequences of the (non)realisation of human rights as well as the anthropological, ethical, ontological and epistemological premise of human rights. Critique and dissensus are inherent to human rights literacies and impact on how we speak and act to in(ex)clusions, marginalisation, intolerance, disrespect, misrecognition and discrimination.

Key words: dissensus, equality, human rights, human rights literacies

\section{INTRODUCTION}

In light of growing global and local critique of human rights, this special edition asked authors to interrogate the ontologies and epistemologies underlying human rights while exploring the possibilities of human rights literacies in higher education contexts. Scholars from a variety of disciplinary fields such as education, curriculum studies, law, education law and social psychology have contributed to this edition. Three contributions to this edition directly address complexities regarding the (non)realisation of abstract rights in terms of categories such as 
gender, sexual minorities and multilingual education. Two of the submissions explore the concepts tolerance and respect - Roux (2017) primarily in the South African context and Ziemens and Abs (2017) in the European context. Three of the contributions address the need for a normative re-evaluation of the premise of transformation, the unanswered normative expectations of students and the assumed normative claims made on behalf of human rights.

What these contributions have in common is the acknowledgement of the inherent conceptual, legal, contextual, historic, normative and material complexities of human rights and, in essence, human rights literacies. Authors emphasise the need for critiquing human rights, the retreat of human rights, a re-imagining of the language of equality in human rights education, a critical shift in human rights education research, a rethink of the moral premise of human rights and an ethical shift in rethinking the possibilities of human rights towards the transformation of higher education especially in South Africa. While human rights have definite transformative potential, the possibilities that injustice can be masked and reproduced within abstract human rights and related policy frameworks are clearly illustrated by the contributions to this special edition. In this article, we briefly touch on two themes emerging from the contributions and the larger body of scholarship on human rights in education. We try to indicate how these might influence not only conceptions of human rights literacies but also point to the urgent need to teach and learn towards human rights literacies.

\section{CRITIQUE, DISSENSUS AND HUMAN RIGHTS LITERACIES.}

Globally, issues such as xenophobia, rising nationalism and populism, linked inter alia to the international migrant crisis, are stretching the past influence and the present reinterpretation of the Universal Declaration of Human Rights (1948) to its limits. Keet, Nel and Sattarzadeh (2017) engage with various lines of critique in their contribution. They argue that it is the critiques of rights that can slice open the pathways for rights to consistently return to its pretheoretical basis'.

In South Africa, the \#MustFall protests at higher education institutions rightly question the existence and validity of human rights, especially as it pertains to the right to education, socio-economic rights and the moral responsibility of these institutions towards its students. Demands for decolonialisation and a shift in the neo-liberal premise of the South African society and educational structures mirror the criticism of scholars such as Žižek, (2005) and Rancière, (2004), arguing that universal human rights are saturated by neo-liberalism and neocolonialism. They pose that human rights centre on exclusions and are ontologically premised on the (non)realisation of rights (cf. Du Preez and Becker 2016). 
For Rancière (2004) there are two forms of rights. Written rights describe the inalienable rights of all humans in documents such as the Universal Declaration of Human Rights (1948) and the South African Bill of Rights (1996). Written rights assume the possibilities of both the existence and non-existence of human rights (Rancière 2004). The second form of rights, Rancière (2004) poses, is concerned with human action within the intersections of possible existing and non-existing human rights. The second form of rights is only realised when the subjects of rights decide to use their rights by constructing dissensus. Dissensus has historically opened disputes of what abstract rights entail, who the subjects of these rights are and where, when and how they should be verified (ibid.). Žižek $(2005,130)$ explains it as follows: 'It was bourgeois "formal freedom" that set in motion the very "material” political demands and practices of feminism or trade unionism'. When the subjects of rights speak and act within the gap enabled by the intersection of existing and non-existing rights, human rights are continually reconstructed.

Dissensus is structured within political spaces. Politics proper and political subjectivication for Rancière (Žižek 2012), started with the emergence of the děmos as an acting agent in the Greek polis. Demanding to be recognised as equal partners in political dialogue was not a rational debate regarding multiple interests, but a struggle to be heard and to be recognised (ibid.). Throughout human history the struggle to be heard, stood against hegemonic and privileged power-interests. One might then question why most human rights discourses are positioned in an uncritical, descriptive and rational realm and are unable to question or address human rights violations. This is answered, through various lenses and in different lived and research contexts, by the authors in this special edition (Du Preez, Simmonds and Chetty 2017; Simmonds and Du Preez 2017; Becker 2017a; Roux 2017; Keet, Nel and Sattarzadeh 2017; De Wet 2017). It seems that human rights have lost their dissident and rebellious spirit (Kapur 2006).

Keet, Nel and Sattarzadeh (2017) argue that human rights have, over the past two decades, globally developed into regimes of control and governmentality. In an age of capitalist and neoliberal managerialism and control, human rights can hardly escape being saturated. For Žižek (2012, 72) political philosophy, have developed a 'kind of defence-formation’ to bring about a return to the pre-political social body. Human rights regimes have in similar fashion bring about over-regulated, managerial human rights frameworks stifling critique on the (non)realisation of human rights in all spheres of human life: political, socio-economic, culture, religion, gender and sexual orientation, age and language. Mkhize and Balfour (2017) specifically speak to the difficulties inherent to language rights and how such difficulties in basic education influence 
multilingual education in higher education

Scholars such as Cistelecan (2011), Žižek (2005) and Rancière (2004) therefore focus their critique of human rights on exclusions (within the frame of abstract rights), the failure to acknowledge the other, identity politics, the moral and political core of universal rights and the capitalist premise of such rights (Du Preez and Becker 2016). Dembour (2010) refers to this body of scholarship on human rights as the discourse school. In a reaction to what scholars from the discourse school perceive as the imperialist and neo-colonial nature of human rights, they argue that human rights do not exist and are only talked about (Dembour 2010). We however agree with Keet, Nel and Sattarzadeh (2017) that critique of human rights do not mean a dismissal of human rights, but present the possibilities for a retreat of rights.

Critique and dissensus in the gap between abstract human rights and the material realities of exploitation, domination, exclusion and marginalisation are crucial to human rights literacies. Teaching and learning towards human rights literacies should therefore be a continually dissonant process, enabling moments of dissensus within intersecting spaces of (non)existing rights. During this process, the multiple subjects of human rights speak to, and act on, the contradictory narratives of exclusions, marginalisation and othering in the gap between abstract rights and their (non)realisation. Although teaching-learning about human rights documents and the values inherent in them is of great importance, the validity and effectiveness of human rights are tested when the processes and the consequences (such as exclusions, othering and marginalisations) inherent to abstract rights frameworks are questioned and critiqued. In defining human rights literacies as both cognitive skills (knowledge of human rights document, remedies and values) and social and moral practices (the processes and consequences of human rights), human rights literacies open spaces in which everyone, everywhere, can engage with issues such as gender violence, the marginalisation of sexual minorities, intolerance, disrespect, (non)recognition and exclusions. (cf. Roux and Becker 2015; Simmonds 2014).

\section{THE (NON)REALISATION OF SUBSTANTIVE EQUALITY}

Of particular interest in the South African context are the contributions speaking of the challenges specific to the realisation of substantive equality. This is problematic as the (non)realisation of substantive equality impacts negatively on the realisation of dignity and freedom. Dignity, equality and freedom (as both legal rights and values) work reciprocally and are linked to one another in the sense that the protection of each is essential for the realisation of the other (Becker, De Wet and Van Vollenhoven 2015). The contribution of Kok (2017) and 
De Wet (2017) specifically speak of this.

The contributions of Du Preez, Simmonds and Chetty (2017) and Keet, Nel and Sattarzadeh (2017), speak of a stifling and ineffective human rights legal and policy environment which result in the construction of over-regulated spaces and practices disabling any transformative possibilities human rights might present in terms of socio-economic rights, gender rights, the protection of sexual minorities or recognition, respect and dignity. Transformative legislation such as the Promotion of Equality and Prevention of Unfair Discrimination Act 4 of 2000 aims to create a more egalitarian society where socio-economic disparities between different communities are softened and furthermore aims to change the 'heart and minds' of South Africans so discrimination and marginalisation can be eradicated (Kok 2017).

Despite transformative legislation and related policies, growing poverty and inequality are endemic to South Africa. Formal equality may have established equal fundamental rights such as the right to vote, but substantive equality in terms of the right to humane living standards, the right to access to quality education and the right to not be discriminated against have not been realised. It follows then that the rights to freedom and dignity are effected.

In line with the aim of the Equality Act to change the 'heart and minds' of South Africans and to construct caring and socially just communities, the articles of Roux (2017), Becker (2017), Keet, Nel and Sattarzadeh (2017) and Du Preez, Simmonds and Chetty (2017) all explore, to various degrees, the need for an ethical shift in rethinking transformation and the transformative potential of human rights in education contexts. Du Preez, Simmonds and Chetty (2017) conceptualise ethics in reference to Badiou $(2002,1)$ as 'the search for a good way of being'. Badiou's ethic of truths is applied to the \#RapeMustFall movements and policies about gender-based violations at higher education institutions. Becker (2017) questions the assumed normative premise(s) of human rights and the link between human rights and responsibilities. For Keet, Nel and Sattarzadeh (2017) the centrality of the rights to 'equality' and 'human dignity' in students' pre-theoretical framings of human rights point to an intuitive, normative expectation of human rights. Roux (2017) in presenting data from six countries including South Africa, similarly found that students regard freedom, respect, social justice and tolerance as the four most important concepts related to human rights. Such normative expectations regard both horizontal and vertical relations structured between self and other within political, educational and socio-economic contexts and speak of the inability of human rights to answer to these expectations.

Students' implicit and explicit (unanswered) normative expectations of human rights, 
inherent to the contributions from Becker (2017), Du Preez, Simmonds and Jetty (2017), Roux (2017), Keet, Nel and Sattarzadeh (2017) and Ziemens and Abs (2017) seem to be a global phenomenon. For Waghid and Davids (2013) material conditions of (non)realised rights and relating violence indicate a need for the global rethink of citizenship, responsibilities, rights and belonging. For them global citizenship is a pedagogical encounter related to equality, intelligibility and amateurism (ibid.). Thinking of oneself as equal within political spaces is the preface to critique and dissensus. The global citizen demands to be recognised as an equal partner in political dialogue and to be heard (cf. Žižek 2012). For Biesta (2010) the assumption in education should be equality. Waghid and Davids (2013) adds to this that equal and intelligible citizens can think, speak and act for themselves. This assume that students, as citizens, neither lack the capacity for speech, nor are they producing noise (Biesta 2010; Roux and Becker 2017). In this view of human rights in education, human rights education and global citizenship education, students announce their presence in political spaces by means of speech and action while learning human rights literacies by which they could speak out when their rights and the rights of others are violated (cf. Waghid and Davids 2013).

Although the contributions to this special edition engage with a wide spectrum of scholarship on human rights in higher education and touch on crucial points of critique, there are still multiple gaps which need to be explored. This includes the neo-liberal and -colonial saturation of human rights and higher education, specifically in the African and South African context, which continuously manifest in onto-epistemologies masking exclusions and othering.

\section{DEMYSTIFYING HUMAN RIGHTS}

Demystifying human rights by means of human rights literacies will unlock an in-depth exploration of the onto-epistemologies of human rights in higher education. An intellectual discourse on the legality of rights is not adequate. A bottom-up teaching, learning and research approach to human rights literacies, exploring onto-epistemologies, should entail multi- and interdisciplinary collaboration, engaging with the lived (non)realisation of rights in categories such as race, ethnicity, culture, gender, language and class. Simmonds and Du Preez (2017) however pose that current human rights education research is uncritical and descriptive.

For Keet (2014) othered and othering epistemologies always have an ontological flavour: 'an othering prior to acknowledgement'. The multiple ontological stances on human rights, as grounded in natural law, in constitutional law, in protesting the rights of the oppressed, in a nihilistic view propagating the (non)existence of human rights, in essentialist and nonessentialist notions, all have in common a search to understand the complexities of human 
rights, but also have ethical, anthropological and epistemological consequences (Roux and Becker 2015; Du Preez and Becker 2016; Dembour 2010).

The onto-epistemologies of (non)existing rights and the normative expectations of human rights therefore require a continual critique of rights. Questions such as: what does posthumanism and the nonhuman turn mean for human rights, and who and what would the decolonised human, as the subject of rights, be for South Africans, are crucial to not only human rights but also higher education in South Africa. We argue that the posthuman decentring of the western liberal human of humanism and human rights may present possibilities for reevaluating the South African and African human, as subject of rights, in human rights. Within post-colonial contexts the potential decolonising of human rights, but also the decolonising possibilities of human rights in a search for multiple peoples and indigenous histories, need to be explored. These integrated and interrelated histories will ascertain inclusion. Such explorations should engage with the ethical, anthropological and onto-epistemological assumptions of the enlightenment premise of human rights (cf. Zembylas 2017).

\section{NOTE}

1. The unexpected and unprecedented nature of the student protests during 2015-2016 came as a shock to many South Africans. Even naming the protests present some difficulties. Students refer to the protests as a movement. In this article, we refer to the student movement as \#MustFall which include: \#Rhodesmustfall, \#Rhodessowhite, \#OpenStellenbosch, \#TransformWits, \#KingGeorgemustfall, \#Thestatuemustfall, \#Feesmustfall, \#Nationalshutdown, \#Feeswillfall, \#ANCmustfall, \#Feeshavefallen, \#Rapemustfall and \#Partriarchymustfall (Booysen 2016) (Becker 2017b).

\section{REFERENCES}

Badiou, A. 2002. Ethics: An essay on the understanding of evil. London \& New York: Verso.

Becker, A. 2017a. Moral responsibility and human rights: Speaking to the 'dark side of human rights.' South African Journal of Higher Education 31(6): 45-60.

Becker, A. 2017b. Rage, loss and other footpaths: Subjectification, decolonisation and transformation in higher education. Transformation in Higher Education 2(0): a23. https://doi.org/ 10.4102/the.v2i0.23

Becker, A., A. de Wet and W. van Vollenhoven. 2015. Human rights literacy: Moving towards rightsbased education and transformative action through understandings of dignity, equality and freedom. South African Journal of Education 35(2): 1-12.

Biesta, G. 2010. Learner, student, speaker: Why it matters how we call those we teach. Educational Philosophy and Theory 42(5-6): 540-552.

Booysen, S. 2016. Introduction. In Fees must fall. Student revolt, decolonialisation and governance in South Africa, ed. S. Booysen. Johannesburg: Wits University Press.

Cistelecan, A. 2011. Which critique of human rights? Evaluating the postcolonialist and the postAlthusserian alternatives. International Journal of Žižek Studies 5(1): 1-13.

Dembour, M. 2010. What are human rights? Four schools of thought. Human Rights Quarterly 32: 1- 
20.

De Wet, A. 2017. Human rights and sexuality - reimagining the language of equality towards transformation in and through education. South African Journal of Higher Education 31(6): 113132

Du Preez, P. and A. Becker. 2016. Ontologies and possibilities of human rights: Exploring dissensus to facilitate reconciliation in post-conflict education contexts. Perspectives in Education 34(3): 114.

Du Preez, P., S. Simmonds and D. John Chetty. 2017. Critical transformation in higher education: Ethical reflections on \#MustFall movements and concomitant gender-based violence. South African Journal of Higher Education 31(6): 96-112.

Keet, A. 2014. Epistemic 'othering' and the decolonising of knowledge. Africa Insight 44(1): 23-37.

Keet, A., W. Nel. and S. D. Sattarzadeh. 2017. Retreating rights: Human rights, pre-theoretical praxes and student activism in South African universities. South African Journal of Higher Education 31(6): 79-95.

Kok, A. 2017. The promotion of equality and prevention of unfair discrimination Act 4 of 2000: How to balance religious freedom and other human rights in the higher education sphere. South African Journal of Higher Education 31(6): 25-44.

Mkhize, D. and R. J. Balfour. 2017. Language rights in education in South Africa. South African Journal of Higher Education 31(6): 133-150.

Rancière, J. 2004. Who is the subject of human rights. The South Atlantic Quarterly 103: 297-310.

Roux, C. 2017. Human rights literacies and students' paradoxical understandings of tolerance and respect. South African Journal of Higher Education 31(6): 61-78.

Roux, C. and A. Becker. 2015. Human rights literacies: Quest for meaning. http://hrlit.org/documents (accessed 10 December 2016).

Roux, C. and A. Becker. 2016. Humanising higher education in South Africa through dialogue as praxis. Education research for social change 5(1): 131-143.

Roux, C. and A. Becker. 2017. On critique, dissensus and human rights. South African Journal of Higher Education 31(6): 1-8.

Simmonds, S. and P. du Preez. 2017. Discourses shaping human rights education research in South Africa: Future considerations. South African Journal of Higher Education 31(6): 9-24.

Simmonds, S. 2014. Mapping the curriculum-making landscape of Religion Education from a human rights education perspective. Journal of the Study of Religion 27: 129-153.

Waghid, Y. and N. Davids. 2013. Citizenship, education and violence. On disrupted potentialities and becoming. Rotterdam: Sense.

Zembylas, M. 2017. Re-contextualisation human rights education: Some decolonial strategies and pedagogical / curriculum possibilities. Pedagogy, Culture and Society 1: 1-12.

Ziemens, J. F. and H. J. Abs. 2017. Strong identities and endorsement of human rights: Conflictive or complementary. South African Journal of Higher Education 31(6): 151-166.

Žižek, S. 2005. Against human rights. New Left Review 34: 115-131.

Žižek, S. 2012. The lesson of Rancière. In The politics of aesthetics, ed. J. Rancière. London: Continuum International Publishing Group. 